\title{
Spectrum of Poisoning and Outcome among Children in a Tertiary Hospital, North-East Nigeria: A 20 Years Restrospective Review, 2000-2019
}

\author{
Warnow Elon Isaac1 ${ }^{*}$, Jalo Iliya1, Sani Adamu², Daniel Apllos ${ }^{3}$, Christianah Oyeniyi ${ }^{4}$ \\ ${ }^{1}$ Department of Paediatrics, College of Medical Sciences, Gombe State University, Gombe, Nigeria \\ ${ }^{2}$ Department of Chemical Pathology, Gombe State University, Gombe, Nigeria \\ ${ }^{3}$ Department of Paediatrics, Federal Teaching Hospital, Gombe, Nigeria \\ ${ }^{4}$ Infectious Diseases Training and Research Group, Gombe, Nigeria \\ Email: ^drwarnow@yahoo.com
}

How to cite this paper: Isaac, W.E., Iliya, J., Adamu, S., Apllos, D. and Oyeniyi, C. (2022) Spectrum of Poisoning and Outcome among Children in a Tertiary Hospital, North-East Nigeria: A 20 Years Restrospective Review, 2000-2019. Open Journal of Pediatrics, 12, 100-124.

https://doi.org/10.4236/ojped.2022.121012

Received: December 14, 2021

Accepted: February 21, 2022

Published: February 24, 2022

Copyright $\odot 2022$ by author(s) and Scientific Research Publishing Inc. This work is licensed under the Creative Commons Attribution International License (CC BY 4.0).

http://creativecommons.org/licenses/by/4.0/

(c) (i) Open Access

\begin{abstract}
Introduction: Acute poisoning in children is cause of hospitalization and death worldwide. It is a Paediatrics emergency with significant economic cost. There are epidemiological differences in acute poisonings in children evaluated in Emergency departments across different countries and regions of the world. The aim of this study was to determine the causes of poisoning in children in our health facility during the period 2000-2019. Methodology: Case notes of children 6 months to 18 years managed for acute poisoning from January 2000 to December 2019 at Paediatrics unit, Federal Teaching Hospital Gombe (FTHG), were analysed. The International classification of Disease ICD 10 was used. Ethical Clearance was obtained. Results: 26,716 children were admitted with 76 cases of Acute poisoning giving a prevalence rate of $2.8 / 1000$ children. $56.6 \%$ (43) were males. $63.2 \%$ (48) of children were $<5$ years of age. $69.7 \%$ (53) were urban dwellers and 59.2\% (45) from low socioeconomic class. 52.6\% (40) of poisoning occurred in rainy season. $97.3 \%$ (74) of children had unintentional poisoning. Organophosphates $22.3 \%$ (17) and kerosine $22.3 \%$ (17) were the most common substances ingested. Snakebite and corrosive ingestion occurred in $13.1 \%$ and $11.8 \%$ of children respectively. Ingestion was the route in $84.2 \%$ of cases. $75.0 \%$ (57) of poisoning occurred at home. ACP occurred in children aged $1-5$ years ( $p$-value $=0.025$ ); More in Children from low socioeconomic status ( $p$-value $=0.001$ ) and urban settings ( $\mathrm{p}$-value $=0.001$ ). There was no statistically significant relation between type of poisoning and gender $\mathrm{p}=0.839$, season $\mathrm{p}=0.608$, religion $\mathrm{p}=$
\end{abstract}


0.504 and ethnic background $p=0.342 .4 .2 \%$ (3) children died each from organophosphate, snake bite and tramadol poisoning. Conclusion: Kerosine and organophosphate were the leading cause of accidental childhood poisoning.

\section{Keywords}

Poisoning, Accidental, childhood, Gombe, Nigeria

\section{Introduction}

Acute poisoning in children is major cause of hospitalisation, disability and death worldwide [1]. It's usually a paediatric emergency with significant economic cost [2] [3]. There are substantial epidemiological differences in acute poisonings in children evaluated in Emergency departments across different countries and regions of the world [4].

While current global estimates are lacking, earlier report indicated that $13 \%$ of global death from accidental poisoning was in children below 20 years of age and mortality was four times higher in developing than developed countries [1]. Every day, 374 children in the United States aged 0 to 19 are treated in an emergency department, and two children die, as a result of being poisoned [5]. In 2019 there were 37.4 poison exposures in children younger than 6 years/1000 children in the USA; Children younger than 6 years comprised $43 \%$ of poison exposures and $99.2 \%$ of exposures were unintentional [6]. In Europe, there is paucity of continent-wide updated data, but each year 3000 young children aged 0 to 14 died of acute poisoning with children 5 years and under accounting for the majority of all poison exposures and children up to two years old especially vulnerable [7].

In India, accidental poisoning was the twelfth leading cause of hospital admission and accounted for $1.0 \%$ of emergency paediatric admissions [8].

In Africa, the extent and burden of poisoning are not known as only ten of 58 countries (17.2\%) had poisons information centres in 2016 [9]. WHO, estimates unintentional poisoning accounted for 39,800 deaths and 27,949,000 DALYs in the UN Africa region in 2012 [10].

In Eastern Africa it was estimated that unintentional poisoning accounted for 16,500 deaths and 1,128,500 DALYs [11].

Acute unintentional poisoning is far more common in children and intentional poisoning both for self-harm behaviour and substance abuse has been implicated in acute poisoning among adolescents. Deliberate and suicidal poisonings among adolescents have been associated with high mortality [12] [13]. Malicious poisoning, though not well studied is an episode where an individual is the victim of another person's intent to harm them through poisoning; it is often challenging to identify the victims, because the available history is typically nonreliable and deliberately deceiving, and the clinical presentations frequently tend 
to mimic natural illnesses [14].

Lead poisoning due to artisanal gold-ore processing activities has had devastating effect in children in mining states of Zamfara and Niger state in Nigeria with an estimated 500 children dead and many more suffering long-term effects; was described as largest in modern times by scope and magnitude. It affected children less than five years old with acute-severe outbreaks [15]. Lead is a cumulative toxicant that affects multiple body systems and is particularly harmful to young children because they absorb $4-5$ times as much ingested lead as adults from a given source [16].

In Nigeria, Earliest studies by Sinnette $\mathrm{CH}$ in Ibadan [17], Ogundipe O [18], Adeyokunnu et al. [19], Oyedeji et al. in Ilesha [20] Diakporomre et al. [21] and the reports of Ango et al. in Zaria [22], Onadeko MO [23], Asindi et al. in Calabar [24], Fagbule et al. in Ilorin [25], Seriki O [26], Olomu IN in Benin [27], and Onifade et al. in Lagos [28], provided substantial glimpse on the epidemiology of acute accidental poisoning in children in the country. Early reports from Ife [29], Maiduguri [30], Ebonyi [31], Kano [32], and Calabar [33], added further epidemiologic depth on acute accidental childhood poisoning in Nigeria.

Recent studies in Nigeria from Warri [34], Jos [35], Enugu [36], Benin [37], Maiduguri [38], Umuahia [39], Azare [40], Ekiti [41], Kano [42], and most recent from Sagamu [43], Abakaliki [44] and Abuja [45], expanded on the pattern and epidemiology of acute poisoning in children in the country. These studies significant as they are in deepening the epidemiology of poisoning in children in Nigeria were generally age restricted, variably short study duration and all were not coded using international classification of disease 10 coding for poisoning. The studies in Nigeria, like our study were hospital based and therefore inherently biased compared to population-based study. In the absence of the coordinated institutional framework for poisoning in Nigeria and in particular the lack of policy, national guideline, and poison prevention, information control centres in the country and indeed many sub-Saharan Africa countries Acute childhood poisoning remains largely underdiagnosed and under reported in children [9] [11].

The aim of the study was to determine the spectrum of acute poisoning and their outcomes in children 6 month - 18 years over a 20 -year period and to compare the findings with other studies conducted in children in the country.

\section{Materials and Methods}

Study design: Retrospective cross sectional analytic study

Study area: This study was conducted in Federal Teaching Hospital (FTH), Gombe [46]. It is a 500-bed health facility located in Gombe, the capital of Gombe state in North East Nigeria. It started providing health care service in 2000. The institution provides basic and tertiary health care services to inhabitants of Gombe. It also serves as referral centre for other tertiary and secondary health facilities from the neighbouring states of Bauchi, Borno, Yobe, Adamawa 
and Taraba states.

\section{Study Site}

The department of Paediatrics in the Teaching Hospital is a 75-bedmedical facility which includes an Emergency Paediatric unit, General Paediatric ward and Special Care Baby Unit.

Study population: children 6 months to 18 years admitted and managed for acute poisoning from January 2000 to December 2019 at Paediatric unit of FTH, Gombe.

Ethical considerations: Ethical clearance was obtained from the research and ethics committee of FTH, Gombe: NHREC/25/10/20/2013

Data collection: All case notes of children 6 months to 18 years admitted and managed for acute poisoning from January 2000 to December 2019 at Emergency Paediatric unit (EPU) FTH, Gombe were retrieved and the following information obtained: age, sex, clinical presentation, type of poisoning, home treatment, hospital treatment, complications, duration of hospital stay and outcome. The International classification of Disease ICD 10 [47] was used to code for poisoning cases. The parental socioeconomic status was determined using Oyedeji [48] classification.

\section{Data analysis}

The data was entered into Excel sheet and analysed using the Statistical Product for Social Science (SPSS) for Windows version 23. Quantitative variables such as age, number of children and people in the family, duration and number of symptoms, was summarized using descriptive statistics such as mean, median and standard deviation. Qualitative variables such as sex, parental socioeconomic class, risk factors and outcome were presented in frequencies and percentages. Case fatality rate was determined by dividing the number of children who died from acute poisoning by total number of patients admitted and managed for unintentional poisoning within the study period. Chi-square $\left(\chi^{2}\right)$ or Fisher's exact tests (where necessary) was used to determine statistical significance of the clinical profile and outcome in the subjects. A $p$-value $<0.05$ was considered significant.

\section{Result}

During the 20 year review a total of 26,716 children aged 0 - 18 years were admitted into the Paediatric Unit. Out of these, seventy-six (76) were admitted for Acute poisoning which constituted $0.28 \%$ of cumulative admissions. This is a prevalence rate of $2.8 / 1000$ children.

\subsection{Socio-Demographic Data}

There were $43(56.6 \%)$ males and 33 females with a male to female ratio of 1.3:1. The mean age of the study population was $5.5296( \pm 0.6239)$. Children age $1-5$ years accounted for $56.6 \%$ of poisoning cases admitted, with those less than 1 year of age constituting 6.6\% (Figure 1). Majority of the patients were urban 
dwellers (69.7\%) and $60.5 \%$ were from monogamous family setting. Children of Fulani ethnicity were the highest (35.5\%), followed by Hausa (17.2\%). Others (36.8\%) included Kanuri, Tangale, Igbo and Yoruba. More than half $(59.2 \%)$ of the studied population were from low socioeconomic class and $27.6 \%$ from high socioeconomic class (Figure 2). Table 1 shows the sociodemographic characteristics of the study population.

Poisoning occurred more commonly in household with more than five children (51.4\%) and in rainy season (52.6\%) than dry season. Only 3 (3.9\%) of cases had behavioural abnormalities, two of these were children with seizure disorders who accidentally took their medication in excess doses. The two (2.6\%) subjects also had delayed developmental milestones (Table 2).

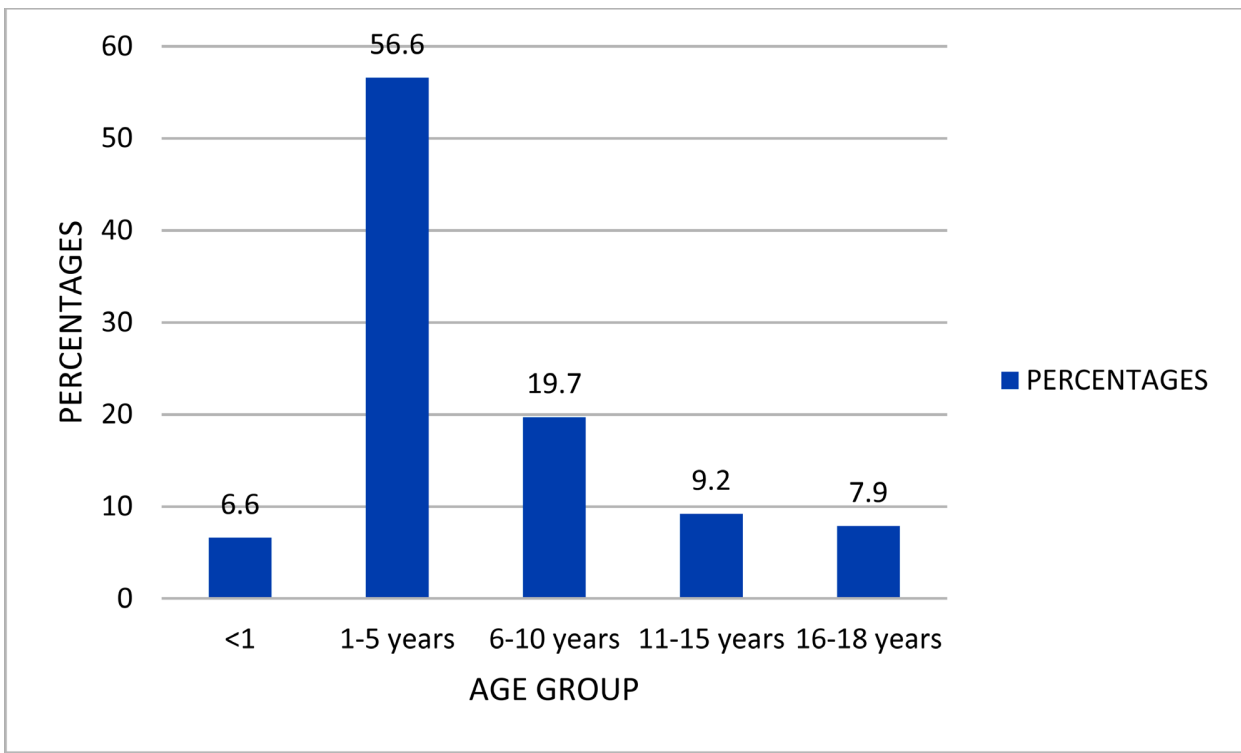

Figure 1. Age group distribution of children with acute poisoning 2000-2019.

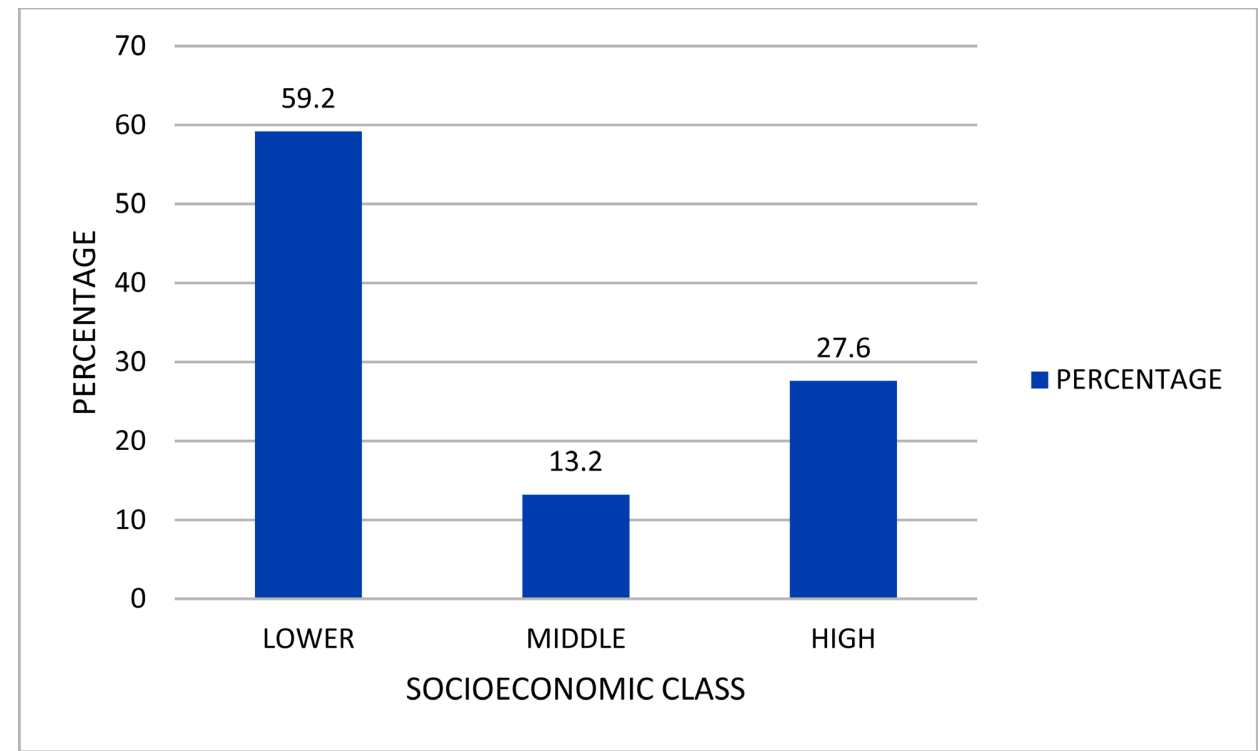

Figure 2. Socioeconomic status of children admitted with Acute Poisoning 2000-2019. 
Table 1. Socio-demographic characteristic of the study population.

\begin{tabular}{|c|c|c|c|}
\hline Variable & Age group & Frequency $(n=76)$ & Percent (\%) \\
\hline \multirow[t]{2}{*}{ Sex } & Males & 43 & 56.6 \\
\hline & Females & 33 & 43.4 \\
\hline \multirow{6}{*}{$\begin{array}{l}\text { Position of index case in the } \\
\text { family }\end{array}$} & $1^{\text {st }}$ & 18 & 23.7 \\
\hline & $2^{\text {nd }}$ & 18 & 23.7 \\
\hline & $3^{\mathrm{rd}}$ & 11 & 14.5 \\
\hline & $4^{\text {th }}$ & 9 & 11.8 \\
\hline & $5^{\text {th }}$ & 9 & 11.8 \\
\hline & Beyond $5^{\text {th }}$ & 11 & 14.5 \\
\hline \multirow{2}{*}{$\begin{array}{l}\text { History of acute poisoning } \\
\text { in the family }\end{array}$} & Yes & 3 & 4.0 \\
\hline & No & 73 & 96.0 \\
\hline \multirow[t]{2}{*}{ Religion } & Islam & 55 & 72.4 \\
\hline & Christianity & 21 & 27.6 \\
\hline \multirow[t]{2}{*}{ Residential address } & Urban & 53 & 69.7 \\
\hline & Rural & 23 & 30.3 \\
\hline \multirow[t]{2}{*}{ Family setting } & Monogamous & 46 & 60.5 \\
\hline & Polygamous & 30 & 39.5 \\
\hline \multirow[t]{6}{*}{ Ethnicity } & Fulani & 27 & 17.2 \\
\hline & Hausa & 13 & 35.5 \\
\hline & Tera & 8 & 10.5 \\
\hline & Kanuri & 4 & 3.9 \\
\hline & Tangale & 3 & 5.2 \\
\hline & Others & 21 & 27.6 \\
\hline
\end{tabular}

Table 2. Biologic and Environmental setting for poisoning.

\begin{tabular}{llcc}
\hline Variables & & Frequency $(\mathbf{n}=76)$ & percent \\
\hline Behavioural anomaly & Present & 3 & 3.9 \\
& Absent & 73 & 96.1 \\
Development mild stones & Normal & 74 & 97.4 \\
& Delayed & 2 & 2.6 \\
Number of children in a & $<5$ & 37 & 48.6 \\
household & $\geq 5$ & 39 & 51.4 \\
Season of poisoning & Dry season (Nov-March) & 36 & 47.4 \\
& Rainy season (April-Oct) & 40 & 52.6 \\
\hline
\end{tabular}




\subsection{Pattern of Poisoning in Children}

Accidental (unintentional) poisoning occurred in $97.3 \%$ of children and intentional in 2.6\%. Table 3 shows the poison agents, route of poisoning and location of poisoning event. Both pesticides and organic solvents were the commonest agents with equal proportion of $23.3 \%$ each. Organophosphates and kerosine were the most common substances children ingested among pesticides and organic solvents respectively. Premium motor spirit(petrol) was ingested/inhaled by a child.

Table 3. Pattern of poisoning among children at Federal Teaching Hospital Gombe 20002019.

\begin{tabular}{|c|c|c|}
\hline Types of poison & $\begin{array}{c}\text { Frequency } \\
(n=76)\end{array}$ & $\begin{array}{c}\text { Percent } \\
(\%)\end{array}$ \\
\hline Accidental & 74 & 97.3 \\
\hline Intentional & 2 & 2.6 \\
\hline Pesticides & 17 & 22.3 \\
\hline Organophosphate (accidental) & 15 & \\
\hline Organophosphate (intentional) & 2 & \\
\hline Organic solvents/petroleum products & 17 & 22.3 \\
\hline Kerosine (accidental) & 16 & \\
\hline Petrol (accidental) & 1 & \\
\hline Snake Bite & 10 & 13.1 \\
\hline Snake bite with toxic effect envenomuos (accidental) & 7 & \\
\hline Snake bite non-envenomuos (accidental) & 3 & \\
\hline Corrosives & 9 & 11.8 \\
\hline Corrosive acid and acid like substance(accidental) & 7 & \\
\hline Corrosive alkali and alkali like substance(accidental) & 2 & \\
\hline Psychotropic drugs & 3 & 3.9 \\
\hline Haloperidol (accidental) & 3 & \\
\hline Antiallergic and antiemetic drugs & 3 & 3.9 \\
\hline Metoclopramide (accidental) & 3 & \\
\hline Narcotic/psychodysleptic drugs & 3 & 3.9 \\
\hline Tramadol (accidental) & 3 & \\
\hline Non-opioid analgesics/antipyretics & 2 & 2.63 \\
\hline Aspirin (accidental) & 1 & \\
\hline Acetaminophen (accidental) & 1 & \\
\hline \multicolumn{3}{|l|}{ Antiviral dugs } \\
\hline Zidovudine (accidental) & 1 & \\
\hline
\end{tabular}




\section{Continued}

\begin{tabular}{|c|c|c|}
\hline Anti-epileptic/Sedative-hypnotic & 3 & 3.95 \\
\hline Benzodiazepine (accidental) & 1 & \\
\hline Carbamazepine (accidental) & 1 & \\
\hline Eucalyptus (accidental) & 1 & \\
\hline $\begin{array}{l}\text { Iron and its compounds } \\
\text { Iron Tablet(accidental) }\end{array}$ & 1 & \\
\hline Unspecified substances (accidental) & 4 & \\
\hline Local detergent (accidental) & 1 & \\
\hline Unspecified substances (accidental) & 3 & \\
\hline Toxic effect of substance eaten as food & 3 & \\
\hline Jimson weed (accidental) & 1 & \\
\hline Plant food Urea fertilizer & 2 & \\
\hline \multicolumn{3}{|l|}{ Route of poisoning } \\
\hline Ingestion & 64 & 84.2 \\
\hline Direct skin contact & 11 & 14.5 \\
\hline Inhalation & 1 & 1.3 \\
\hline \multicolumn{3}{|l|}{ Location of poisoning event } \\
\hline Home & 57 & 75.0 \\
\hline Kitchen & 32 & 56.1 \\
\hline Bedroom & 1 & 1.7 \\
\hline Others & 24 & 42.1 \\
\hline Neighbourhood & 11 & 14.5 \\
\hline Farm & 7 & 9.2 \\
\hline School & 1 & 1.3 \\
\hline \multicolumn{3}{|l|}{ Pack of the poison } \\
\hline Drink container & 14 & 18.4 \\
\hline Food container & 12 & 15.8 \\
\hline Drug sachet & 7 & 9.2 \\
\hline Others & 43 & 56.6 \\
\hline
\end{tabular}

Snake bite and corrosive ingestion also occurred in $13.1 \%$ and $11.8 \%$ of children respectively. Toxic effect of snake bite as a result of envenomation occurred in $70 \%$ of all cases of Snake bite. Of the corrosives ingested, acid and acid like substances occurred in $75 \%$ of cases. Ingestion was the common route of poisoning (84.2\%) while poisoning by inhalation was rare (1.3\%). Three-quarter of the poisoning occurred at home with more than half (56.1\%) in the kitchen and $1.7 \%$ in the bed room. One case of poisoning $1(1.3 \%)$ took place in the school 
environment. Other places of poisoning were neighbourhood (14.5\%) and farmland (9.2\%). More than two-third (65\%) of the poison substances were packaged in drink and food container while $17.5 \%$ of drugs were kept in their package within the reach of the children.

\subsection{Clinical Presentation and Outcome of Poisoning in Children}

Table 4 presents the clinical features and outcome of children with acute poisoning

Table 4. Clinical presentations and outcome of acute poisoning in children 2000-2019

\begin{tabular}{|c|c|c|}
\hline Variables & Frequency $(n=76)$ & Percent (\%) \\
\hline \multicolumn{3}{|c|}{ Duration(hrs) before presentation } \\
\hline$<1$ Hour & 12 & 15.8 \\
\hline $1-5$ hours & 29 & 38.2 \\
\hline$>5$ hours & 35 & 46.1 \\
\hline \multicolumn{3}{|l|}{ Symptoms at presentation } \\
\hline Vomiting & 18 & 23.7 \\
\hline Fast breathing & 12 & 15.8 \\
\hline Unconsciousness & 9 & 11.8 \\
\hline Cough & 8 & 10.5 \\
\hline Limb swelling \& pain & 8 & 10.5 \\
\hline Abdominal pain & 8 & 10.5 \\
\hline Convulsion & 6 & 7.9 \\
\hline Bleeding & 2 & 2.6 \\
\hline Others & 5 & 6.5 \\
\hline \multicolumn{3}{|l|}{ Home remedy } \\
\hline Milk & 28 & 56.0 \\
\hline Palm oil & 7 & 14.0 \\
\hline Herbal concoction & 5 & 10.0 \\
\hline Tourniquet \& Incision & 4 & 8.0 \\
\hline Others & 6 & 12.0 \\
\hline \multicolumn{3}{|l|}{ Duration of Hospital stay } \\
\hline$<72 \mathrm{hrs}$ & 52 & 68.4 \\
\hline $3-7$ days & 14 & 18.4 \\
\hline 1 - 2 weeks & 8 & 10.5 \\
\hline$>2$ weeks & 2 & 2.6 \\
\hline \multicolumn{3}{|l|}{ Outcome } \\
\hline Discharged & 72 & 94.5 \\
\hline Died & 3 & 4.2 \\
\hline Left against Medical Advice & 1 & 1.3 \\
\hline
\end{tabular}


over the period of review. Fifty-four percent (41) of children presented within 5 hours of ingestion of poisoning. Majority (23.7\%) of the patients presented with vomiting as the principal complaints, $15.8 \%$ and $10.5 \%$ presented with fast breathing and cough respectively. Nine children $(11.8 \%)$ presented with loss of consciousness. Convulsion was reported among $7.9 \%$ of the children. Limb swelling and pain (10.5\%) was the presenting complaint among those with snake bite and envenomation.

Various home interventions were given to patients before presentation to the hospital facility. Common among these were; milk (56.0\%), palm oil (14.0\%), herbal concoction (10.0\%) and incision and torniquet (8.0\%). Other (12.0\%) rare home remedies included; administration of tamarind, Oral rehydration solution, and Salted drinks, activated charcoal and immersion into water. More than twothird (68.4\%) of the patients were discharged within seventy-two hours. Two (2.6\%) of the patients who developed complications (corrosive stricture and sulphuric burns) were on admission for more than two weeks.

Three out of the 76 cases admitted died during admission giving a case fatality rate of $4.2 \%$. Death was each from organophosphate, snake bite and tramadol poisoning in 18 year, 2 years and 6 months old children respectively. All death cases were males, presented in coma, from Low socioeconomic class and died within 72 hours of admission. One (1.3\%) patient left against medical advice. Table 4 shows the clinical presentation and outcome of the cases.

Most of the children received various interventions while on admission, except $9.2 \%$ of cases who were only observed and discharged. Intravenous fluid (77.6\%), antibiotics (41.6\%) and intranasal oxygen (23.7\%) were the common hospital intervention given. Gastric decontamination was done in $2(2.6 \%)$ patients. Anti-snake venom was administered to all those with envenomation.

\subsection{Poisoning and Some Sociodemographic Characteristics}

Acute accidental Poisoning occurred among children age 1 - 5 years with a significant p-value of 0.025 . Children from low socioeconomic status and urban dwellers were statistically more likely to be accidentally involved in poisoning than those from high socioeconomic status and rural dwellers (P-value: 0.001). There was also a likelihood of poisoning occurring in rainy season than in dry season. Although poisoning occurred commonly in males with male to female of ratio of 1.3:1, there was no statistically significant relationship in such occurrence (p-value: 0.29 ). Similarly, there was no statistically significant relation between type of poisoning and, gender $\mathrm{p}=0.839$, season $\mathrm{p}=0.608$, religion $\mathrm{p}=$ 0.504 and ethnic background $\mathrm{p}=0.342$. Table 5 shows the correlation of the type of poisoning and the sociodemographic variables of the studied subjects.

\section{Discussion}

Public health initiatives for preventing poisoning in Nigeria and globally must be predicated on evidence about the types of exposures in health facilities and the 
W. E. Isaac et al.

Table 5. Correlation between type of poisoning and some sociodemographic variables.

\begin{tabular}{|c|c|c|c|c|c|c|c|}
\hline \multirow{2}{*}{\multicolumn{2}{|c|}{ Sociodemographic variables }} & \multicolumn{5}{|c|}{ Type of poison } & \multirow{3}{*}{$\begin{array}{r}\text { P. value } \\
0.003\end{array}$} \\
\hline & & \multirow{2}{*}{$\begin{array}{c}\text { Household agent } \\
2\end{array}$} & \multirow{2}{*}{$\frac{\text { Medicines }}{3}$} & \multirow{2}{*}{$\begin{array}{c}\text { Agrochemicals } \\
0\end{array}$} & \multirow{2}{*}{$\begin{array}{c}\text { Envenomation } \\
0\end{array}$} & \multirow{2}{*}{$\begin{array}{c}\text { Others } \\
0\end{array}$} & \\
\hline Age (Yrs.) & $<1$ & & & & & & \\
\hline & $1-5$ & 21 & 9 & 8 & 1 & 4 & \\
\hline & $6-10$ & 2 & 3 & 5 & 3 & 2 & \\
\hline & $11-15$ & 1 & 1 & 1 & 2 & 2 & \\
\hline & $16-18$ & 0 & 1 & 1 & 4 & 0 & \\
\hline \multirow[t]{2}{*}{ Residential address } & Rural & 23 & 15 & 7 & 4 & 4 & 0.002 \\
\hline & Urban & 3 & 2 & 8 & 6 & 4 & \\
\hline \multirow[t]{3}{*}{ Socio-economic class } & Lower & 12 & 8 & 13 & 8 & 3 & 0.020 \\
\hline & Middle & 6 & 0 & 2 & 1 & 1 & \\
\hline & High & 8 & 9 & 0 & 1 & 3 & \\
\hline \multirow[t]{2}{*}{ Season } & Dry & 14 & 8 & 6 & 3 & 5 & 0.608 \\
\hline & Rainy & 12 & 9 & 9 & 7 & 3 & \\
\hline \multirow[t]{2}{*}{ Gender } & Male & 14 & 10 & 8 & 5 & 6 & 0.839 \\
\hline & Female & 12 & 7 & 7 & 5 & 2 & \\
\hline \multirow[t]{2}{*}{ Religion } & Christianity & 5 & 7 & 3 & 3 & 3 & 0.504 \\
\hline & Islam & 21 & 10 & 12 & 7 & 5 & \\
\hline \multirow[t]{8}{*}{ Tribe } & Hausa & 6 & 3 & 2 & 1 & 1 & 0.342 \\
\hline & Fulani & 8 & 4 & 7 & 5 & 3 & \\
\hline & Tera & 5 & 3 & 0 & 0 & 0 & \\
\hline & Tangale & 0 & 1 & 0 & 1 & 1 & \\
\hline & Igbo & 0 & 0 & 0 & 0 & 1 & \\
\hline & Yoruba & 0 & 1 & 0 & 0 & 1 & \\
\hline & Kanuri & 1 & 1 & 2 & 0 & 0 & \\
\hline & Others & 6 & 4 & 4 & 3 & 1 & \\
\hline \multirow[t]{2}{*}{ Outcome } & Alive & 26 & 16 & 14 & 9 & 8 & 0.588 \\
\hline & Dead & 0 & 1 & 1 & 1 & 0 & \\
\hline
\end{tabular}

community [49]. Our study, a 20-year hospital-based review, using ICD 10 classification is an attempt at providing robust evidence for public policy in Nigeria. In spite of its drawback in hospital coding for poisoning [49] [50], the ICD 10 remains the most important classification.

In the first generation reports [17]-[28] on poisoning in children in Nigeria between 1969 and 1999 prevalence reported ranged between 0.9\% and 3.8\%. While our study prevalence rate of $0.3 \%$ is lower than the first generation reported range, studies [29]-[45] from year 2000 to 2020 reported lower preva- 
lence rates of between $0.2 \%$ and $1.5 \%$. This observed difference could be attributable to methodologic issues with the first-generation studies being generally shorter in duration compared with the second-generation studies; age category and limit varied and in addition, the denominator too varied between total emergency paediatrics unit admissions and total paediatrics ward admissions. Both generation studies [17]-[45] were generally 10 years and below in duration except the report of Oguche et al. [30] that is comparable to our study. Oguche et al. [30] reported acute poisoning in children less than 13 years compared to 18 years in this present study. Comparable prevalence of $0.22 \%, 1.7 \%$ and $0.95 \%$, have been reported in Qatar [51], India [52], Ghana [53], and Cameroon [54] respectively.

Children 5 years and under account for the majority of all poison exposures with children up to two years old especially vulnerable. [1]

Children less than 2 years formed the peak age group for poisoning in the first-generation studies by Ogundipe [18], Oyedeji [20], Ango et al. [22], Asindi [24], Fagbule et al. [25], Onifade [20].

Similar findings were reported by these studies [29] [34] [44] [45]. Our study and others [28] [30] [31] [32] [35] [36] [37] [40] reported peak age for poisoning in children as less than five years of age.

Curiosity and the desire to put everything in their mouths place young children at considerably greater risk for poison exposure than adults [55].

In our study, more males than females were affected and this is similar to most first and second-generation reports in Nigeria. Females predominated in reports from Jos [35] and Port-Harcourt [2] and Turkey [56]. However, these differences were generally not statistically significant. This is similar to reports from other countries [52] [53] [54].

The most obvious risk factor for ingestion of a substance is its presence in the domestic environment, within reach of the child [1].

In our study, most of the poisoning events occurred in the home environment. This is similar to recent reports from Jos [35], Azare [40], Ado-Ekiti [41], Sagamu [43] and Ghana [53], Turkey [56], Sri Lanka [57] and Taiwan area [58]. Most other first [17] [21] [22] [23] [24] [25] [27] [28], and second [29]-[34] generation studies in the country did not report where poisoning took place; although the assumption was the home environment. The farm, neigbourhood, market, bakery, Shop, Creche, religious camp were reported as some sites of childhood poisoning [34] [40] [41] [44].

Rainy season recorded most poisoning events compared to dry season in our study but this was however not statistically significant. Our finding is similar to the report from Umuahia [39] in Southern Nigeria but in contrast to studies in Zaria 22 and Maiduguri [30] situated in the far north of the country. Several poisoning studies [21] [24] [25] [28] [33] [34] [35] [36] [38] [40] [41] [43] [44] [45] in the country did not report season of occurrence in Children. In dry season temperatures are high, young children are likely to be outdoors, may consume more fluids and are at risk of poisoning [1]. In the rainy season and cold 
weather, requirements for heating and heating appliances increase, indoor confinement and exposure to medications put these children at risk for poisoning [1].

Organic solvents and pesticides were equally the dominant form of poison agents in children in our report. Specifically, Kerosine and organophosphates were the commonest substances ingested. The predominance of these two agents has been reported recently from Jos [35] and most recently from Azare [40] and Abuja [45] in the North of the country. Across almost all of the first [2] [17] [18] [20] [22] [23] [24] [25] [27] [28] and second-generation studies [29]-[37] [39] [41] [42] [43] in the country, kerosine was commonest cause of childhood poisoning reported. While there is wide variation among studies in percentage contribution of kerosine, Maiduguri [30], Enugu [36] and Zaria [22] reported highest percentages of $78.8 \%, 67.7 \%$ and $67.5 \%$ respectively. Our study and those of Jos [35] and Azare [40] reported lowest kerosine incidences of 22.3\%, 23.1\%, $24.4 \%$ respectively. Kerosine was also the leading substance in reports from Ghana [53], Cameroun [54], Sri-Lanka [57] and South Africa [59].

Organophosphate was the most common cause of ACP in our study. Reports from Azare [40], Jos [35] and Abuja [45] showed high percentage of Organophosphates as agents of unintentional poisoning in Children. Some early reports from Ibadan [17], Lagos [28], Zaria [22], Calabar [24] and later reports from Warri [34], Ado Ekiti [41], Sagamu [43], Enugu [36], Port Harcourt [2], Umuahia [39], Maiduguri [30], Abakalilki [44] reported pesticides in forms of organophosphates, herbicides, rodenticides in various forms in childhood accidental poisoning. Pesticide poisoning is therefore common in Nigeria and probably underreported. They have been identified as one of the dangerous poisons in the paediatric age group [60] and an important cause of poisoning in children in east African [11] and South East Asian regions [57]. As low- and mediumincome countries boost their agricultural production, children often suffer from more serious accidental poisonings and pesticides are the most popular means of self-harm in LMICs leading to most of the deadly pesticide poisonings [61]. Severe chronic diseases have been linked to pesticide exposure including cancer and impaired neurological development of children exposed in utero [62]. Exposures leading to such chronic effects might also stem from pesticide intake from residues in food and drinking water [63].

In our study, drugs and medicines closely followed organophosphate and kerosine as the third leading cause of poisoning in Children. This is similar to reports from Lagos [28], Calabar [33], Jos [35], Enugu [36], Warri [34], Azare [40] and Abuja [45]. Studies from Ibadan [17], Zaria [22] and Ilorin [25] and later reports from Ado-Ekiti 41 found drugs and medicines as the second leading cause of poisoning in children. These other reports showed medicines and drugs as causes of childhood poisoning [2] [30] [38] [39]. Across the country, pharmaceutical products are emerging as causes of accidental poison especially in children but like other agents are perhaps underdiagnosed and under reported. These pharmaceutical products are the leading causes of accidental poisoning in 
middle- and high-income countries like USA [64], Taiwan area [58], Turkey [56], Egypt [65], Singapore [66], Sirilanka [67], South Africa [68], and Brazil [69]. Studies from Sagamu [43] and Abakalilki [44] did not find drugs and medicines as cause of poisoning. Patterns of poisoning with medicinal drugs change across different geographic regions and over decades owing to variability in prescription practice, sociocultural factors, safe storage of medicines, and free availability of over-the-counter medications [67].

Snake bites with envenomation were a significant contributor to accidental poisoning in our study. Snake bites as part of accidental poisoning constituted 5.4\% in Ibadan [17] and 4.0\% in Port Harcourt [2] studies. Isolated studies on snake bites in children had been reported earlier by Ogala et al. in Zaria, [70] Sani et al. in Sokoto [71], and both Nduagubam et al. [72] and Ndu et al. in Enugu [73].

The higher prevalence of snake bites in our study relates to the proximity of our study site to the area in Gombe state with one of the highest snake bite prevalence in the country [74] [75] [76].

In our study, most of the snake bites occurred during the rainy season. This is similar to reports from Sokoto [70] and Enugu [71] [72] and specie identification of the snake was low in these reports which is also similar to our study. Studies on snake bites from Ghana [77], South Africa [75], Morocco [76], and Taiwan area [58] showed disproportionate involvement of children.

Snakebites are concentrated in mainly rural areas and vary considerably by season, with the peak incidence seen in the rainy and harvesting seasons with fatality rates among children generally higher [78]. In contrast to many other serious health conditions, a highly effective treatment exists. High quality snake antivenoms are the most effective treatment to prevent or reverse most of the venomous effects of snake bites [79] [80] [81].

In a first-generation report, Diakporomre [21] reported local alcoholic brew (ogogoro) as commonest cause of poison in children in Benin; and in later studies from Calabar [33], Benin [37] and Warri [34] alcohol was the second common cause of acute unintentional poisoning in children. Alcohol was also reported in studies from Umuahia [39], Port Harcourt [2], Lagos [28], Sagamu [43] and Ado-Ekiti [41].

Locally distilled gin was available in most homes and sold by many people as a source of livelihood and features in traditional functions [24]. Occasionally, parents allowed young children to sip the local gin [27] in poorly stored containers [33]. No reports of poisoning from alcohol from the northern part of the country. Alcohol poisoning in children has also been reported in several countries [54] [58] [66].

Approximately $10 \%$ of paediatric poisonings were due to recreational/illicit drugs. These events typically involved ethanol [4].

With only about $30 \%$ of the adult population drinking alcohol in Africa, and with expected increases in the number of potential new alcohol consumers and a change towards a "public, binge drinking culture over the weekends" children 
are at risk of acute unintentional poison [82]. Being at the center of social and cultural activities in many countries, towns and villages, geographical differences exist among the type of alcohol people consume and therefore the risk to children [83].

Corrosives constituted the fifth leading cause of poisoning in our study. Corrosives have also been earlier reported by workers from Ibadan [17], Lagos, [28], Ife [29], Calabar [33], Warri [34], Enugu [36], Umuahia [39], Ado-Ekiti [41], Sagamu [43]. Caustic soda, Bleach and acids were common forms of corrosives reported.

Corrosives have been shown to be significant contributors to childhood poisoning [84] [85] [86] [87].

Acid ingestions cause injury to the stomach and less likely to cause oesophageal and pharyngeal injury because of the resistance of squamous epithelium to coagulation necrosis. Alkaline ingestions injure the oesophagus and pharynx causing liquefactive necrosis and tissue oedema that affects the squamous epithelium [88] [89].

While poisoning from food was very low in our study, food poisoning was the first and second leading causes of childhood poisoning in the two studies from Maiduguri [30] [38]. Studies from Port Harcourt [2], Zaria [22] and Ilorin [25] also reported low incidence of food as a source of acute poisoning in children. Childhood food poisoning have been reported from Ghana [53], Egypt [90], India [91] and Ethiopia [92].

Children are at risk of food poisoning and almost a third of deaths from food poisonings around the world are in children under age 5, even as these children make up less than 10 percent of the world's population [93].

In our study, acute unintentional poisoning occurred in children from low socioeconomic background. This is similar to reports from Ile-Ife [29], Maiduguri [30] [38], Enugu [36], Warri [34], Sagamu [43], Abakalilki44 but in contrast to the report from Abuja, [45] the capital city of the country. Low socioeconomic status is strongly associated with morbidity and mortality from poisoning reports from Sri Lanka [57], Pakistan [94], Australia [95], Japan [96], Egypt [97], Scotland [98] and Pakistan [99].

In low socioeconomic households, children are disadvantaged as a result of low parental education, lack of parental awareness and knowledge about poison, risk of poison, poor parental supervision, local beliefs and customs, larger family size or children in family, unsafe storage of medicines and household chemicals and are at higher odds of accidental poisoning [67].

The incidence of intentional poisoning in our study is similar to reports from Warri 2.4\% [34], Sagamu 3.2\% [43] but lower than reports from Jos 7.7\% [35] and Ado-Ekiti 14.8\% [41]. In our review, two adolescent females intentionally ingested organophosphates with death in one of them. Organophosphates was the agent for intentional poisoning in adolescents [8] [12] especially in females [100]. There was paucity of reports on intentional poisoning in the first-generation studies in Nigeria. However, there is increasing documentation of evidence of intentional poi- 
soning; with pesticides and corrosives as the commonest agents in children in the country [34] [35] [41] [43] [101]. It is estimated that $15 \%-33 \%$ of suicides in Africa were from pesticide self-poisoning [102].

Generally higher incidence of deliberate self-poisoning has been reported in other countries with adolescent females predominating [56] [58] [66] [84] [92]. The lifetime prevalence of non-suicidal self-injury in literature is estimated to vary between $7.5 \%$ and $8 \%$ for preadolescents, increasing to $12 \%$ and $23 \%$ among adolescents [103]. Suicide and deliberate self-harm are generally higher in high income countries compared to low- and medium-income countries [8].

Identifying intentional poisoning is crucial as it can either be an attempt for non-suicidal self-injurious behaviour for attention seeking or a suicidal attempt where the intention is death. Underlying mental health, behavioural challenges or child abuse should be excluded [104] [105].

The home remedy for accidental poisoning was milk and palm-oil administered to these children in this review. Palm oil, milk or a combination of both were the commonest remedy in both first [22] [24] [25] [27] and second generation studies [2] [29] [30] [35] [36] [39] [41] [43] [44] [45] in Nigeria. Several other reported pre-hospital treatment agents administered singly or in combination included Palm Kernel oil, coconut oil, Honey, Prayer water, induction of vomiting, raw egg, Herbal mixtures and Magnesium trisilicate. Home remedies or first aid measures before arriving the hospital are potentially harmful and can complicate the clinical course of children with acute unintentional poisoning [22] [25] [106].

Overall, the management of poisoning in children with both accidental and intentional poison depends on factors such as the type of poison, the "dose, as it is the poison", clinical manifestation, age, presence of other diseases or injury, the time of poisoning exposure WHO 2008 [1], USA poison control centre 2019 [6] and the home remedy especially in our environment. Ife [29], Maiduguri [30].

In our study, 3 patients died with the overall mortality of $4.2 \%$. This mortality rate is higher than the highest rate of 3.8\% [22] reported in the first-generation studies [17]-[28]. The mortality rates in the first-generation report ranged between $0.7 \%$ [21] and 3.8\% [22]. Our mortality rate is within the range of $0 \%$ [30] [39] and 18.2\% [45] reported in the second-generation studies. Mortality rates in accidental poisoning in children were generally higher in the second generation reports [29]-[45] in Nigeria. While the reason for this cursory difference in mortality rates between the first and second generation studies is unclear to us, Childhood poisoning in Nigeria is a cause of preventable deaths and requires a well-coordinated national response.

The case fatality rate from snake bite in our study of $10 \%$ was higher than the $0 \%$ and $7.7 \%$ from recent reports from Sokoto [71] and Enugu [72] respectively; $2.7 \%$ and $3.0 \%$ in earlier studies from Zaria [70] and Sokoto [107] respectively too. A far higher CFR of $24.6 \%$ was reported during an outbreak of snake bite in 
Taraba Sate [108].

Mortality from snake bite is related to venom type, delayed hospital access and availability of appropriate and high quality antisnake venom [109] [110] [111].

In this review, case fatality from organophosphate poisoning was $11.7 \%$; this is higher than reports from China [112] 1.4\% Sirilanka 1.9\% [67]. Egypt 5.5\% [113] Nepal (5.9\%) [114] and Tanzania [100] 3.8\% but within the mortality range of $4 \%$ - 30\% following OP poisoning [115].

Tramadol case fatality was $33.3 \%$. in our study which was far higher than the $14.2 \%$ in France [116] $10.5 \%$ in those aged 10 to 19 and $1.7 \%$ in children younger than 10 years in Iran [117] and 9\% in Bangladash [118] Children will bear disproportionately, the consequence of the opiod epidemic in sub-Saharan Africa [119].

\section{Conclusion}

Pesticides and hydrocarbons were the leadings agents in acute unintentional poisoning in children in our study. Early identification and treatment are critical to preventing morbidity and mortality.

\section{Limitation}

Retrospective nature of the study

\section{Recommendation}

Development of National policy and guideline and establishment of poison prevention, information control centres in Nigeria.

\section{Acknowledgements}

We wish to acknowledge the staff of medical health records coding unit.

\section{Authors' Contribution}

Isaac Warnow Elon: Conceived of the study and study design, developed the first manuscript draft, and critically reviewed all drafts of the manuscript.

JaloIliya: Oversaw the study design and critically reviewed all drafts of the manuscript.

Sani Adamu, Apollos Daniel, Oyeniyi Christianah: Conducted quantitative analysis and critically reviewed the final manuscript.

\section{Conflicts of Interest}

The authors declare no conflicts of interest regarding the publication of this paper.

\section{References}

[1] World Health Organization (2008) World Report on Child Injury Prevention. World 
Health Organization, Geneva.

https://apps.who.int/iris/bitstream/handle/10665/43851/9789241563574 eng.pdf

[2] Ikhile, I., Chijioke-Nwauche, I. and Orisakwe, O.E. (2019) Childhood Drug and Non-Drug Poisoning in Nigeria: An Economic Appraisal. Annals of Global Health, 85, 100. https://doi.org/10.5334/aogh.2544

[3] Benabdellah, F.Z., Soulaymani, A., Mokhtari, A., et al. (2020) Economic Evaluation of the Direct Cost Resulting from Childhood Poisoning in Morocco: Micro-Costing Analysis. Arch Public Health, 78, Article No. 59.

https://doi.org/10.1186/s13690-020-00440-Z

[4] Mintegi, S., Azkunaga, B., Prego, J., Qureshi, N., Dalziel, S.R., et al., on Behalf of the Pediatric Emergency Research Networks (PERN) Poisoning Working Group (2019) International Epidemiological Differences in Acute Poisonings in Pediatric Emergency Departments. Pediatric Emergency Care, 35, 50-57.

https://doi.org/10.1097/PEC.0000000000001031

[5] Protect the Ones You Love Poisoning (2021) https://www.houston.k12.tn.schools.bz.userfiles/25/poisoning-Fact-sheet-a.pdf

[6] Poison Control (2019) Poison Statistics National Data 2019. Reports to U.S. Poison Control Center. https://www.poison.org/poison-statistics-national

[7] World Health Organization (2008) The Global Burden of Disease: 2004 Update. World Health Organization, Geneva.

https://www.who.int/healthinfo/global burden disease/GBD report 2004update f ull.pdf

[8] Kurshid, A.W., Musadir, A., Imran, G. and Shafia, A. (2015) Pattern of Pediatric Poisoning in Kashmir (Incidence, Clinical Profile and Outcome): A Hospital Based Study. International Journal of Advanced Research, 3, 513-519.

[9] Marks, C., van Hoving, N., Edwards, N., et al. (2016) A Promising Poison Information Centre Model for Africa. African Journal of Emergency Medicine, 62, 64-69. https://doi.org/10.1016/j.afjem.2015.09.005

[10] World Health Organization (2014) DALY Estimates: WHO Member States, 2012, Estimates for 2002-12. Disease Burden. World Health Organization, Geneva. https://www.who.int/healthinfo/global-burden-disease/GBD-report2004update.part 4.pdf

[11] Tagwireyi, D., Chingombe, P., Khoza, S., et al. (2016) Pattern and Epidemiology of Poisoning in the East African Region: A Literature Review. Journal of Toxicology, 2016, Article ID: 8789624. https://doi.org/10.1155/2016/8789624

[12] Tay, E.Y., Tan, G.F., Yeo, A.W.C. and Tham, E.H. (2020) Intentional Poisoning in Pediatric Patients: Examining the Risk Factors. Pediatric Emergency Care, 37, e1510e1514. https://doi.org/10.1097/PEC.0000000000002101

[13] Alanazi, M.Q. and Salam, M. (2017) Intentional Poisoning among Preadolescents at One Poison Center in Saudi Arabia. Indian Journal of Child Health, 4, 44-48. https://doi.org/10.32677/IJCH.2017.v04.i01.012

[14] Gauthey, M., Capua, M., Brent, J., Finkelsteinon, Y., on Behalf of the Toxicology Investigators (2019) Consortium Poisoning with Malicious or Criminal Intent: Characteristics and Outcome of Patients Presenting for Emergency Care. Clinical Toxicology, 57, 628-631. https://doi.org/10.1080/15563650.2018.1546009

[15] Medecins Sans Frontier (2012, May 11) Lead Poisoning Crisis in Zamfara State Northern Nigeria Paper.

https://www.msf.org/lead-poisoning-crisis-zamfara-state-northern-nigeria

[16] World Health Organization (2019) Lead Poisoning and Health. 
https://www.who.int/news-room/fact-sheets/detail/lead-poisoning-and-health

[17] Sinnette, C.H. (1969) The Pattern of Childhood Accidents in South-Western Nigeria. Bulletin of the World Health Organization, 41, 905-914.

[18] Ogundipe, O. (1975) Poisoning in children in an Urban Area of Nigeria. Nigerian Journal of Medicine, 5, 341-347.

[19] Adeyokunnu, A.A., Taiwo, O. and Antia, A.U. (1980) Childhood Mortality among 22,255 Consecutive Admissions in UCH Ibadan. Nigerian Journal of Paediatrics, 7, 43-45.

[20] Oyedeji, G.O., Olamijulo, S.K. and Joiner, K.T. (1980) Poisoning in Children in Ilesha. Nigerian Journal of Paediatrics, 10, 227-234.

[21] Diakparomre, M.A. and Obi, J. (1980) Pattern of Paediatric Emergencies in the University of Benin Teaching Hospital. Nigerian Journal of Paediatrics, 7, 43-45.

[22] Ango, S.S. and Yakubu, A.M. (1982) Accidental Childhood Poisoning in Zaria. Nigerian Journal of Paediatrics, 9, 105-109.

[23] Onadeko, M.O. (1983) Domestic Accidents among Rural and urban Children in Nigeria. Nigerian Journal of Paediatrics, 10, 10-23.

[24] Asindi, A.A. (1984) Accidental Poisoning in Calabar. Nigerian Journal of Paediatrics, 11, 19-22.

[25] Fagbule, D. and Ojuwao, A. (1986) Accidental Childhood Poisoning in Ilorin. Nigerian Journal of Paediatrics, 13, 21.

[26] Seriki, O. (1983) Accidental Poisoning in Children. Postgraduate Doctor, 5, 142-147.

[27] Olomu, I.N. (1992) Accidental Childhood Poisoning in Benin City. Nigerian Journal of Paediatrics, 19, 24-29.

[28] Onifade, E.U. (1999) Accidental Poisoning in Childhood at the Lagos University Teaching Hospital. Nigerian Journal of Paediatrics, 26, 4.

[29] Adejuyigbe, E.A., Onayade, A.A., Senbanjo, I.O. and Oseni, S.E. (2002) Childhood Poisoning at the Obafemi Awolowo University Teaching Hospital Ile Ife, Nigeria. Nigerian Journal of Medicine, 11, 183-186.

[30] Oguche, S., Bukbuk, D.N. and Watila, I.M. (2007) Pattern of Hospital Admissions of Children with Poisoning in the Sudano-Sahelian North Eastern Nigeria. Nigerian Journal of Clinical Practice, 10, 111-115.

[31] Ibekwe, R.C., Amadife, M.U., Muoneke, V.U. and Onyire, B.N. (2007) Accidental Childhood Poisoning in Ebonyi State University Teaching Hospital (Ebsuth). Abakaliki, South Eastern Nigeria. Ebonyi Medical Journal, 6, 26-29.

https://doi.org/10.4314/ebomed.v6i1.41496

[32] Belonwu, R.O. and Adeleke, S.I. (2008) A Seven-Year Review of Accidental Kerosene Poisoning in Children at Aminu Kano Teaching Hospital, Kano. Nigerian Journal of Medicine, 17, 380-382. https://doi.org/10.4314/njm.v17i4.37415

[33] Ochigbo, S.O., Udoh, J.J. and Antia-Obong, O.E. (2004) Accidental Childhood Poisoning in Calabar at the Turn of the 20th Century. Nigerian Journal of Paediatrics, 31, 67-70. https://doi.org/10.4314/njp.v31i3.12103

[34] Ugwu, G.I.M., Okperi, B.O., Ugwu, E.N., et al. (2012) Childhood Poisoning in Warri, Niger Delta, Nigeria: A Ten Year Retrospective Study. African Journal of Primary Health Care \& Family Medicine, 4, Article No. a321, 5 p. https://doi.org/10.4102/phcfm.v4i1.321

[35] Shwe, D.D., Toma, B., Pate, S.I., Adedeji, I. and Oguche, S. (2013) Profile of Hospital Admissions of Childhood Poisoning at a North-Central Nigerian Tertiary Health Care Centre. Jos Journal of Medicine, 7, 5-7. 
[36] Edelu, B.O., Odetunde, O.I., Eke, C.B., Uwaezuoke, N.A. and Oguonu, T. (2016) Accidental Childhood Poisoning in Enugu, South-East, Nigeria. Annals of Medical and Health Science Research, 6, 168-171. https://doi.org/10.4103/2141-9248.183944

[37] Abhulimhen-Iyoha, B.I. and Israel-Aina, Y.T. (2018) Pattern of Accidental Childhood Poisoning at the Children Emergency Room of the University of Benin Teaching Hospital, Benin City, Nigeria. West African Journal of Medicine, 35, 85-89.

[38] Yakubu, M., Ahmadu, B.U., Simon, P., Yerima, T.S., Umaru, H.I. and Dauda, M.I. (2013) Pattern of Accidental Childhood Poisoning in University of Maiduguri Teaching Hospital: A Sudano Sahelian Region of Northern Nigeria. International Journal of Phytopharmacy Research, 4, 59-63.

[39] Ibeneme, C.A., Ogbonna, I.F. and Nwala, G.C. (2018) Accidental Poisoning among Under-Five Children Seen at the Children's Emergency Room of Federal Medical Center Umuahia, Nigeria. International Journal of Medicine and Health Development, 23, 201-205

[40] Imoudu, I.A.M., Afegbua, D.S., Elike, M., Ishola, I. and Abubakar, A. (2018) Acute Childhood Poisoning in Azare North Eastern Nigeria. Journal of Advances in Medicine and Medical Research, 26, 1-8. https://doi.org/10.9734/JAMMR/2018/41050

[41] Olatunya, O.S., Isinkaye, A.O., Ogundare, E.O., Oluwayemi, I.O. and Akinola, F.J. (2015) Childhood Poisoning at a Tertiary Hospital in South West Nigeria. Journal of Nepal Paediatric Society, 35, 103-110. https://doi.org/10.3126/jnps.v35i2.12548

[42] Abubakar, S., Ahmed, A., Farouk, Z., Gadanya, M. and Jimoh, M.L. (2018) Prevalence and Pattern of Unintentional Domestic Accidents and Trauma amongst Children Attending Public Hospitals in Kano, Nigeria. Sahel Medical Journal, 21, 6-12. https://doi.org/10.4103/1118-8561.232787

[43] Oba-Daini, O.U., Ogunlesi, T.A., Adekanmbi, A.F. and Akodu, S.O. (2020) Childhood Poisoning in Sagamu South West Nigeria. Nigerian Journal of Paediatrics, 47, $1-5$.

[44] Obu, D.C., Orji, M.C., Muineke, U.V., Agiegbu, U.V. and Ezegbe, G.O. (2020) Accidental Childhood Poisoning in Paediatric Department of a Tertiary Health Care Facility. Nigerian Journal of Paediatrics, 47, 215-220.

https://doi.org/10.4314/njp.v47i3.4

[45] Ahmed, P.A., Nwatah, V.E. and Ulonnam, C.C. (2020) Childhood Accidental Poisoning among Hospitalised Children in a Tertiary Health Care in North Central Nigeria-A Two Year Prospective Report. Nigerian Journal of Paediatrics, 47, 221 226. https://doi.org/10.4314/njp.v47i3.5

[46] Federal Teaching Hospital Gombe, Nigeria. http://fthgombe.org.ng

[47] World Health Organization (2010) International Statistical Classification of Diseases and Related Health Problems. 10th Revision, Vol. 2, 2010 Edition, World Health Organization, Geneva.

https://www.who.int/classifications/icd/ICD10Volume2 en 2010.pdf

[48] Oyedeji, G.A. (1995) Socioeconomic and Cultural Background of Hospitalized Children in Ilesha. Nigerian Journal of Paediatrics, 12, 111-117

[49] Huynh, A., Cairns, R., Brown, J.A., et al. (2018) Patterns of Poisoning Exposure at Different Ages: The 2015 Annual Report of the Australian Poisons Information Centres. Medical Journal of Australia, 209, 74-79. https://doi.org/10.5694/mja17.01063

[50] Du, W., Pearson, S.A., Buckley, N.A., et al. (2017) Diagnosis-Based and External Cause-Based Criteria to Identify Adverse Drug Reactions in Hospital ICD-Coded Data: Application to an Australia Population-Based Study. Public Health Research 
and Practice, 27, Article ID: 2721716. https://doi.org/10.17061/phrp2721716

[51] Ahmed, A., Al Jamal, A.N., Ibrahim, M.I.M., Salameh, K., Al Yafei, K., et al. (2015) Poisoning Emergency Visits among Children: A 3-Year Retrospective Study in Qatar. BMC Pediatrics, 15, Article No. 104. https://doi.org/10.1186/s12887-015-0423-7

[52] Agarwal, G., Bithu, K.S. and Agarwal, R. (2016) An Epidemiological Study of Acute Poisoning in Children in a Tertiary Care Hospital of western Rajasthan, India. Int J Contemp Pediatr, 3, 1249-1251. https://doi.org/10.18203/2349-3291.ijcp20163653

[53] Ansong, D., Nkyi, C., Appiah, C.O., Amuzu, E.X., Frimpong, C.A., Nyanor, I., et al. (2016) Epidemiology of Paediatric Poisoning Reporting to a Tertiary Hospital in Ghana. South African Journal of Child Health, 10, 68-70. https://doi.org/10.7196/SAJCH.2016.v10i1.1055

[54] Nguefack, F.A., Chiabi, N., Sandrine, B., Jean, M., Evelyn, S., Nguefack, A., et al. (2017) Clinical and Epidemiologic Study on Unintentional Domestic Poisoning at the Paediatric Service of the Yaounde Gynaeco-Obstetric and Pediatric Hospital. Journal of Medical Research, 3, 164-168. https://doi.org/10.31254/jmr.2017.3314

[55] National SAFE KIDS Campaign (2004) Poisoning Fact Sheet. National SAFE KIDS Campaign, Washington DC.

[56] Ozdemir, R., Bayrakci, B., Tekşam, O., Yalçin, B. and Kale, G. (2012) Thirty-ThreeYear Experience on Childhood Poisoning. Turkish Journal of Pediatrics, 54, 251259.

[57] Dayasiri, M.B.K.C., Jayamanne, S.F. and Jayasinghe, C.Y. (2018) Patterns and Outcome of Acute Poisoning among Children in Rural Sri Lanka. BMC Pediatrics, 18, Article No. 274. https://doi.org/10.1186/s12887-018-1246-0

[58] Lee, J., Fan, N.C., Yao, T.C., Hsia, S.H., Lee, E.P., Huang, J.L., et al. (2019) Clinical Spectrum of Acute Poisoning in Children Admitted to the Pediatric Emergency Department. Pediatrics \& Neonatology, 60, 59-67.

https://doi.org/10.1016/j.pedneo.2018.04.001

[59] Balme, K.H., Roberts, J.C., Glasstone, M., Curling, L. and Mann, M.D. (2012) The Changing Trends of Childhood Poisoning at a Tertiary Children's Hospital in South Africa. South African Medical Journal, 102, 142-146. https://doi.org/10.7196/SAMJ.5149

[60] Riordan, M.R.G. and Berry, K. (2002) Poisoning in Children 5: Rare and Dangerous Poisons. Archives of Disease in Childhood, 87, 407-410.

https://doi.org/10.1136/adc.87.5.407

[61] Jørs, E., Neupane, D. and London, L. (2018) Pesticide Poisonings in Low- and Middle-Income Countries. Environ Health Insights, 12, Article ID: 1178630217750876. https://doi.org/10.1177/1178630217750876

[62] London, L., Beseler, C., Bouchard, M.F., et al. (2012) Neurobehavioral and Neurodevelopmental Effects of Pesticide Exposures. NeuroToxicology, 33, 887-896.

https://doi.org/10.1016/j.neuro.2012.01.004

[63] Reiler, E., Jørs, E., Bælum, J., Huici, O., Alvarez Caero, M.M. and Cedergreen, N. (2015) The Influence of Tomato Processing on Residues of Organochlorine and Organophosphate Insecticides and Their Associated Dietary Risk. Science of the Total Environment, 527-528, 262-269.

https://doi.org/10.1016/j.scitotenv.2015.04.081

[64] Centres for Disease Control (2016) Picture of America Poisoning Fact Sheet.

[65] Azab, S.M., Hirshon, J.M., Hayes, B.D., El-Setouhy, M., Smith, G.S., et al. (2016) 
Epidemiology of Acute Poisoning in Children Presenting to the Poisoning Treatment Center at Ain Shams University in Cairo, Egypt, 2009-2013. Clinical Toxicology, 54, 20-26. https://doi.org/10.3109/15563650.2015.1112014

[66] Koh, S.H., Tan, K.H.B. and Ganapathy, S. (2018) Epidemiology of Paediatric Poisoning Presenting to a Children's Emergency Department in Singapore over a FiveYear Period. Singapore Medical Journal, 59, 247-250. https://doi.org/10.11622/smedj.2018053

[67] Dayasiri, K., Jayamanne, S.F. and Jayasinghe, C.Y. (2020) Accidental and Deliberate Self-Poisoning with Medications and Medication Errors among Children in Rural Sri Lanka. Emergency Medicine International, 2020, Article ID: 9872821, 8 p. https://doi.org/10.1155/2020/9872821

[68] Veale, D.J., Wium, C.A. and Müller, G.J. (2013) Toxicovigilance. I: A Survey of Acute Poisonings in South Africa Based on Tygerberg Poison Information Centre Data. South African Medical Journal, 103, 293-297. https://doi.org/10.7196/SAMJ.6647

[69] Vilaça, L., Volpe, F.M. and Ladeira, R.M. (2019) Accidental Poisoning in Children and Adolescents Admitted to a Referral Toxicology Department of a Brazilian Emergency Hospital. Revista Paulista de Pediatria, 38, Article ID: e2018096. https://doi.org/10.1590/1984-0462/2020/38/2018096

[70] Ogala, W.N. and Obaro, S.K. (1999) Venomous Snake Bites in Children in the Tropics: The Zaria Experience. Nigerian Medical Practitioner, 26, 11-13.

[71] Sani, U.M., Jiya, N.M., Ibitoye, P.K. and Ahmad, M.M. (2013) Presentation and Outcome of Snake Bite among Children in Sokoto, North-Western Nigeria. Sahel Medical Journal, 16, 148-153.

[72] Nduagubam, O.C., Chime, O.H., Ndu, I.K., Bisi-Onyemaechi, A., Eke, C.B., et al. (2020) Snakebite in Children in Nigeria: A Comparison of the First Aid Treatment Measures with the World Health Organization's Guidelines for Management of Snakebite in Africa. Annals of African Medicine, 19, 182-187. https://doi.org/10.4103/aam.aam $38 \quad 19$

[73] Ndu, I.K., Edelu, B.O. and Ekwochi, U. (2018) Snakebites in a Nigerian Children Population: A 5-Year Review. Sahel Medical Journal, 21, 204-207. https://doi.org/10.4103/smj.smj $18 \quad 18$

[74] Yusuf, P.O., Mamman, M., Ajagun, E., Suleiman, M.M., Kawu, M.U., et al. (2015) Snakes Responsible for Bites in North-Eastern Nigeria-A Hospital Based Survey. Toxicology and Food Technology, 9, 118-121.

[75] Wood, D., Sartorius, B. and Hift, R. (2016) Snakebite in North-Eastern South Africa: Clinical Characteristics and Risks for Severity, South African Family Practice, 58, 62-67. https://doi.org/10.1080/20786190.2015.1120934

[76] Eljaoudi, R., Larréché, S., Chakir, S., Chafiq, F., Hmyene, A., et al. (2019) Snake Bites in Morocco: Progress and Challenges. Advances in Toxicology and Toxic Effects, 3, 9-14. https://doi.org/10.17352/atte.000004

[77] Punguyire, D., Baiden, F., Nyuzaghl, J., Hultgren, A., Berko, Y., et al. (2014) Presentation, Management, and Outcome of Snake-Bite in Two District Hospitals in Ghana. Pan African Medical Journal, 19, Article No. 219.

https://doi.org/10.11604/pamj.2014.19.219.5267

[78] Chippaux, J.P. (2011) Estimate of the Burden of Snakebites in sub Saharan Africa: A Meta-Analytic Approach. Toxicon, 57, 586-599.

https://doi.org/10.1016/j.toxicon.2010.12.022 
[79] https://www.who.int/news-room/fact-sheets/detail/snakebite-envenoming

[80] Warrell, D.A. (2010) Snake Bite. Lancet, 375, 77-88. https://doi.org/10.1016/S0140-6736(09)61754-2

[81] Habib, A.G. (2013) Public Health Aspects of Snakebite Care in West Africa: Perspectives from Nigeria. Journal of Venomous Animals and Toxins including Tropical Diseases, 19, Article No. 27. https://doi.org/10.1186/1678-9199-19-27

[82] Ferreira-Borges, C., Parry, C.D. and Babor, T.F. (2017) Harmful Use of Alcohol: A Shadow over Sub-Saharan Africa in Need of Workable Solutions. International Journal of Environmental Research and Public Health, 14, Article No. 346. https://doi.org/10.3390/ijerph14040346

[83] World Health Organization (2011) Global Status Report on Alcohol and Health. World Health Organization, Geneva.

https://www.who.int/substance abuse/publications/global alcohol report/msbgsru profiles.pdf

[84] Sahin, S., Carman, K.B. and Dinleyici, E.C. (2011) Acute Poisoning in Children; Data of a Pediatric Emergency Unit. Iranian Journal of Pediatrics, 21, 479-484.

[85] Aqeel, M., Munir, A. and Khan, A. (2009) Pattern and Frequency of Acute Poisoning in Children. Pakistan Journal of Medical Sciences, 25, 479-483.

[86] Kazanasmaz, H., Kazanasmaz, O. and Çalık, M. (2019) Epidemiological and Sociocultural Assessment of Childhood Poisonings. Turkish Journal of Emergency Medicine, 19, 127-131. https://doi.org/10.1016/j.tjem.2019.06.001

[87] Jayashree, M. and Singhi, S. (2011) Changing Trends and Predictors of Outcome in Patients with Acute Poisoning Admitted to the Intensive Care. Journal of Tropical Pediatrics, 57, 340-346. https://doi.org/10.1093/tropej/fmq099

[88] Chirica, M., Bonavina, L., Kelly, M.D., Sarfati, E. and Cattan, P. (2017) Caustic Ingestion. Lancet, 389, 2041-2052. https://doi.org/10.1016/S0140-6736(16)30313-0

[89] Kurowski, J.A. and Kay, M. (2017) Caustic Ingestions and Foreign Bodies Ingestions in Pediatric Patients. Pediatric Clinics of North America, 64, 507-524. https://doi.org/10.1016/j.pcl.2017.01.004

[90] Abd-Elhaleem, Z.A., Abd-Elkarim, M.A. (2011) Pattern of Food Poisoning in Egypt, a Retrospective Study. Journal of Pharmacology and Toxicology, 6, 505-515. https://doi.org/10.3923/jpt.2011.505.515

[91] Pramila, R. and Nilesh, J. (2021) A Study about Clinic-Epidemiological Pattern of Acute Poisoning in Pediatric Age Group. Asian Journal of Medical Sciences, 12, 4853. https://doi.org/10.3126/ajms.v12i4.30701

[92] Woyessa, H.A., Palanichamy, T. (2020) Patterns, Associated Factors, and Clinical Outcomes of Poisoning among Poisoning Cases Presented to Selected Hospitals in Western Ethiopia: Hospital-Based Study. Emergency Medicine International, 2020, Article ID: 5741692, 9 p. https://doi.org/10.1155/2020/5741692

[93] https://www.who.int/news/item/03-12-2015-who-s-first-ever-global-estimates-of-fo odborne-diseases-find-children-under-5-account-for-almost-one-third-of-deaths

[94] Ahmed, B., Fatmi, Z., Siddiqui, A.R. (2011) Population Attributable Risk of Unintentional Childhood Poisoning in Karachi Pakistan. PLoS ONE, 6, Article ID: e26881. https://doi.org/10.1371/journal.pone.0026881

[95] Schmertmann, M., Williamson, A., Black, D., et al. (2013) Risk Factors for Unintentional Poisoning in Children Aged 1-3 Years in NSW Australia: A Case-Control Study. BMC Pediatrics, 13, Article No. 88. https://doi.org/10.1186/1471-2431-13-88 
[96] ESato, N., Hagiwara, Y., Ishikawa, J., et al. (2018) Association of Socioeconomic Factors and the Risk for Unintentional Injuries among Children in Japan: A CrossSectional Study. BMJ Open, 8, Article ID: e021621. https://doi.org/10.1136/bmjopen-2018-021621

[97] Seif, E., Gomaa, R. and Eisa, M. (2106) A Retrospective Study of Acute Poisoning in Children under 5 Years Old Admitted to Alexandria Poison Center in Egypt. World Journal of Preventive Medicine, 4, 32-39.

[98] Henery, P.M., Dundas, R., Katikireddi, S.V., Leyland, A., Wood, R., et al. (2021) Social Inequalities and Hospital Admission for Unintentional Injury in Young Children in Scotland: A Nationwide Linked Cohort Study. Lancet Regional Health, Europe, 6, Article ID: 6100117. https://doi.org/10.1016/j.lanepe.2021.100117

[99] Manzar, N., Saad, S.M.A., Manzar, B. and Fatima, S.S. (2010) The Study of Etiological and Demographic Characteristics of Acute Household Accidental Poisoning in Children-A Consecutive Case Series Study from Pakistan. BMC Pediatrics, 10, Article No. 28. https://doi.org/10.1186/1471-2431-10-28

[100] Lekei, E., Ngowi, A.V., Kapeleka, J., et al. (2020) Acute Pesticide Poisoning amongst Adolescent Girls and Women in Northern Tanzania. BMC Public Health, 20, Article No. 303. https://doi.org/10.1186/s12889-020-8374-9

[101] Eze, J.N., Ndu, I.K. and Edelu, B.O. (2018) Teenage Organophosphate Insecticide Poisoning: An Ugly Trend in Enugu Nigeria. Journal of Community Medicine and Primary Health Care, 30, 99-108.

[102] Mew, E.J., Padmanathan, P., Konradsen, F., Eddleston, M., Chang, S.-S., et al. (2017) The Global Burden of Fatal Self-Poisoning with Pesticides 2006-15: Systematic Review. Journal of Affective Disorders, 219, 93-104. https://doi.org/10.1016/j.jad.2017.05.002

[103] Washburn, J.J., Richardt, S.L., Styer, D.M., Gebhardt, M., Juzwin, K.R., et al. (2012) Psychotherapeutic Approaches to Non-Suicidal Self-Injury in Adolescents. Child and Adolescent Psychiatry and Mental Health, 6, Article No. 14. https://doi.org/10.1186/1753-2000-6-14

[104] Bacha, T., Tilahun, B. (2015) A Cross-Sectional Study of Children with Acute Poisoning: A Three-Year Retrospective Analysis. World Journal of Emergency Medicine, 6, 265-269. https://doi.org/10.5847/wjem.j.1920-8642.2015.04.003

[105] World Health Organization (2014) Preventing Suicide. A Global Perspective.

[106] Dayasiri, M.B.K.C., Jayamanne, S.F. and Jayasinghe, C.Y. (2017) Kerosene Oil Poisoning among Children in Rural Sri Lanka. International Journal of Pediatrics, 2017, Article ID: 8798610. https://doi.org/10.1155/2017/8798610

[107] Njoku, C.H., Isezuo, S.A. and Makusidi, M.A. (2008) An Audit of Snake Bite Injuries Seen at the Usmanu Danfodiyo University Teaching Hospital Sokoto, Nigeria. Nigerian Postgraduate Medical Journal, 15, 112-115

[108] Igawe, P.B., Omar, J., Nwokoro, U., Difa, J. and Isah, S.I. (2020) Snakebite Outbreak and Associated Risk Factors in Donga, Taraba State, Nigeria, June, 2016. Pan African Medical Journal, 37, Article No. 82.

[109] Habib, A.G. and Abubakar, S.B. (2011) Factors Affecting Snakebite Mortality in North-Eastern Nigeria. International Health, 3, 50-55.

https://doi.org/10.1016/j.inhe.2010.08.001

[110] Iliyasu, G., Tiamiyu, A.B., Daiyab, F.M., Tambuwal, S.H., Habib, Z.G., Habib, A.G. (2015) Effect of Distance and Delay in Access to Care on Outcome of Snakebite in Rural North-Eastern Nigeria. Rural Remote Health, 15, Article No. 3496. https://doi.org/10.22605/RRH3496 
[111] Ademola-Majekodunmi, F.O., Oyediran, F.O. and Abubakar, S.B. (2012) Incidence of Snakebites in Kaltungo, Gombe State and the Efficacy of a New Highly Purified Monovalent Antivenom in Treating Snakebite Patients from January 2009 to December 2010. Bulletin de la Société de pathologie exotique, 105, 175-178. https://doi.org/10.1007/s13149-012-0232-2

[112] Wang, N., Jiang, Q., Han, L., et al. (2019) Epidemiological Characteristics of Pesticide Poisoning in Jiangsu Province, China, from 2007 to 2016. Scientific Reports, 9, Article No. 8604. https://doi.org/10.1038/s41598-019-44986-7

[113] Abdel Baseer, K.A., Gad, E.F., Abdel Raheem, Y.F. (2021) Clinical Profile and Outcome of Acute Organophosphate Poisoning in Children of Upper Egypt: A Cross-Sectional Study. BMC Pediatrics, 21, Article No. 98. https://doi.org/10.1186/s12887-021-02563-w

[114] Koirala, D.P., Rao, K.S., Malla, K.K. and Malla, T. (2013) A Study of Clinical Features, Management and Outcome of Organophosphate and Carbamate Poisoning In Children. Journal of Nepal Paediatric Society, 33, 85-90. https://doi.org/10.3126/jnps.v33i2.7799

[115] Yamashita, M., Yamashita, M., Tanaka, J. and Ando, Y. (1997) Human Mortality in Organophosphate Poisoning. Veterinary and Human Toxicology, 39, 84-85.

[116] Tanné, C., Javouhey, E., Millet, A. and Bordet, F. (2016) Severe Tramadol Overdoses in Children: A Case Series Admitted to Paediatric Intensive Care Unit. Journal of Clinical Toxicology, 6, Article No. 317. https://doi.org/10.4172/2161-0495.1000317

[117] Iravani, F.S., Akhgari, M., Jokar, F., Bahmanabadi, L. (2010) Current Trends in Tramadol-Related Fatalities, Tehran, Iran 2005-2008. Substance Use \& Misuse, 45, 2162-2171. https://doi.org/10.3109/10826081003692098

[118] Rahman, M., Chowdhury, M.A., Hoque, M., Hossain, M. and Suman, G.M. (2019) Tramadol Suppository Poisoning in Children of Bangladesh. Bangladesh Journal of Child Health, 43, 157-160. https://doi.org/10.3329/bjch.v43i3.49572

[119] Kurth, A.E., Cherutich, P., Conover, R., Chhun, N., Bruce, R.D., Lambdin, B.H. (2018) The Opioid Epidemic in Africa And Its Impact. Current Addiction Reports, 5, 428-453. https://doi.org/10.1007/s40429-018-0232-9 